\title{
EML4/ALK Fusion Protein Variant 4
}

National Cancer Institute

\section{Source}

National Cancer Institute. EML4/ALK Fusion Protein Variant 4. NCI Thesaurus. Code C99738.

A fusion protein (1097 aa, 121 kDa) that is encoded by the EML4/ALK variant 4 fusion gene. This protein is comprised of the $\mathrm{N}$-terminal half of the echinoderm microtubuleassociated protein-like 4 fused to the entire cytoplasmic domain of the ALK tyrosine kinase receptor protein including the tyrosine kinase domain. 